\title{
Pengembangan Perangkat Pembelajaran Aktif dengan Metode Practice Rehearsal Pairs pada Materi Suhu dan Kalor Untuk Meningkatkan Penguasaan Konsep Fisika
}

\author{
Zahratur Raodah ${ }^{*}$, Jannatin 'Ardhuha1, Muh. Makhrus' ${ }^{1}$ \\ ${ }^{1}$ Program Studi Pendidikan Fisika, FKIP Universitas Mataram, Mataram, Indonesia.
}

DOI: https://doi.org/10.29303/goescienceedu.v2i1.126

\section{Article Info}

Received : 22 Maret 2021

Revised : 15 Juni 2021

Accepted: 30 Juni 2021

Abstract: Pembelajaran merupakan proses komunikasi antara guru dengan peserta didik. Proses pembelajaran akan berhasil apabila peserta didik mencapai kompetensi yang diharapkan, karena hal tersebut dapat menggambarkan kemampuan peserta didik dalam menguasai suatu materi. Seorang guru harus mampu memilih dan menggunakan metode pembelajaran yang tepat dan efektif. Penelitian ini bertujuan untuk mengembangkan perangkat pembelajaran aktif dengan metode practice rehearsal pairs yang layak digunakan dalam pembelajaran dan dapat meningkatkan penguasaan konsep fisika peserta didik. Penelitian ini merupakan penelitian pengembangan (research and development (R\&D)) dengan desain model pengembangan 4D yang terdiri atas 4 tahapan yaitu: define (pendefinisian); design (perancangan); develop (pengembangan); dan desseminate (penyebarluasan). Kondisi pandemi membuat penelitain ini hanya sampai pada tahap develop (pengembangan). Berdasarkan validasi oleh ahli, pengembangan perangkat pembelajaran dalam penelitian ini cukup valid dan reliabel. Persentase validitasnya sebesar $80,83 \%$ pada silabus; $83,33 \%$ pada rencana pelaksanaan pembelajaran; dan $79,17 \%$ pada lembar kerja peserta didik. Sedangkan, persentase relibialitasnya sebesar $89,40 \%$ pada silabus; $89,70 \%$ pada rencana pelaksanaan pembelajaran; dan 91,20\% pada lembar kerja peserta didik. Berdasarkan hasil tersebut, pengembangan perangkat pembelajaran dalam penelitian ini layak digunakan dengan revisi, karena memiliki kriteria cukup valid.

Kata Kunci: Perangkat Pembelajaran; Practice Rehearsal Pairs; Penguasaan Konsep

\begin{abstract}
Learning is a process of communication between teachers and students. The learning process will be successful if students achieve the expected competencies, because it can describe the ability of students to master a material. A teacher must be able to choose and use appropriate and effective learning methods. This research aims to develop active learning tools with practice rehearsal pairs methods that are suitable for use in learning and can improve students' mastery of physics concepts. This research is a research and development (R\&D) with a $4 \mathrm{D}$ development model design consisting of 4 stages, namely: define; design; develop; and disseminate. The pandemic condition has made this research only at the develop stage. Based on validation by experts, the development of learning tools in this research is quite valid and reliable. The percentage of validity is $80.83 \%$ on the syllabus; $83.33 \%$ on the lesson plan implementation; and $79.17 \%$ on student worksheets. Meanwhile, the percentage of reliability is $89.40 \%$ on the syllabus; $89.70 \%$ on the lesson plan implementation; and $91.20 \%$ on student worksheets. Based on these results, the development of learning tools in this research is feasible to use with revisions, because it has quite valid criteria.
\end{abstract}

Keywords: Learning Devices; Practice Rehearsal Pairs; Concept Mastery

\section{Pendahuluan}

Belajar adalah suatu proses psikis yang berlangsung dalam interaksi antara subjek dengan lingkungannya dan menghasilkan perubahanperubahan dalam pengetahuan, pemahaman, keterampilan, sikap dan kebiasaan yang bersifat relatif konstan/tetap baik melalui pengalaman, latihan 
maupun praktik. Perubahan itu bisa sesuatu yang baru atau hanya penyempurnaan terhadap hal-hal yang sudah dipelajari yang segera nampak dalam perilakuny atau yang masih tersembunyi (Ardiansyah: 2013). Menurut Suprijono (2014), belajar adalah bentuk pengalaman yang merupakan hasil dari interaksi antara peserta didik dengan lingkungannya. Seorang guru harus mampu memberikan lingkungan yang mendukung peserta didik untuk mendapatkan pengalaman belajar yang baik.

Berdasarkan hasil observasi yang dilakukan di MAN 2 Mataram pada bulan Mei kegiatan pembelajaran daring (dalam jaringan) memberikan tantangan tersendiri kepada guru untuk mampu menyampaikan materi pembelajaran kepada peserta didik dengan sebaik mungkin kemudian peserta didik dapat memahaminya. Guru menyampaikan materi pembelajaran dengan model pembelajaran langsung dalam melaksanakan pembelajaran daring. Guru menemukan beberapa kesulitan dalam melaksanakan pembelajaran daring diantaranya hanya sebagian kecil peserta didik yang mau terlibat aktif dalam pembelajaran daring misalnya aktif bertanya dan merespon pertanyaan-pertanyaan langsung dari guru, sehingga guru belum sempat untuk menerapkan model dan metode pembelajaran lainnya. Hikmawati (2014) memaparkan bahwa tidaklah cukup bagi seorang guru hanya menggantungkan diri pada satu pendekatan atau metode pembelajaran. Guru dengan bermodalkan kemampuan melaksanakan berbagai model pengajaran dapat memilih model yang sesuai dengan keadaan lingkungan belajar atau keadaan sekelompok peserta didik yang diharapkan mampu mendorong peserta didik untuk ikut berperan aktif dalam kegiatan belajar mengajar.

Menurut Warsono (2012) guru merupakan fasilitator yang membantu peserta didik untuk belajar dan memiliki keterampilan-keterampilan yang diperlukan dalam mencapai tujuan pembelajaran dimana fasilitas yang disediakan oleh guru dalam pembelajaran menggambarkan suatu proses dalam membawa seluruh anggota kelompok untuk berpartisipasi dalam pembelajaran dengan asumsi bahwa setiap peserta didik memiliki sifat unik yang bernilai untuk saling dipertukarkan. Fasilitas dalam hal ini salah satunya dapat berupa perangkat pembelajaran yang disiapkan oleh guru guna mengatur seluruh peserta didik dapat berpartisipasi dalam pembelajaran di kelas.

Silberman (2009) memaparkan bahwa pembelajaran dengan metode practice rehearsal pairs atau praktik berpasangan merupakan metode sederhana untuk mempraktikkan dan mengulang keterampilan dengan pasangan belajar untuk memastikan bahwa kedua pasangan belajar dapat mempraktekkan dan mengulang keterampilan tersebut. Hasil penelitian yang dilakukan Suriani et. al. (2019) juga memaparkan dalam penelitiannya bahwa hasil belajar peserta didik menggunakan metode pembelajaran aktif tipe practice rehearsal pairs lebih baik dari pada menggunakan pembelajaran konvensional. Kelebihan metode practice rehearsal pair selain dapat meningkatkan motivasi peserta didik juga dapat meningkatkan partisipasi antar peserta didik dalam pembelajaran, karena setiap peserta didik akan mendapatkan peran untuk menjadi penjelas dan observer, dengan peran-peran tersebut tentu peserta didik akan aktif dalam mengikuti dan menjalankan proses pembelajaran yang sedang berlangsung (Munfaridatus: 2018).

Berdasarkan pemaparan diatas, maka peneliti bermaksud untuk mengembangkan perangkat pembelajaran aktif dengan metode practice rehearsal pairs untuk meningkatkan penguasaan konsep fisika agar dapat dijadikan referensi bagi guru dalam melaksanakan pembelajaran daring.

\section{Metode}

Metode yang digunakan dalam penelitan ini adalah metode penelitian dan pengembangan atau Research and Development (R\&D). Metode penelitian dan pengembangan adalah metode penelitian yang digunakan untuk mengembangkan dan memvalidasi produk pendidikan (Setyosari: 2012). Desain penelitian yang digunakan adalah desain model pengembangan 4D yang terdiri atas 4 tahapan yaitu: (1) define (pendefinisian); (2) design (perancangan); (3) develop (pengembangan); (4) desseminate (penyebarluasan). Kondisi pandemi membuat penelitian ini hanya sampai pada tahap develop (pengembangan).

Rochmad (2012) menguraikannya dalam penjabaran sebagai berikut.

1. Tahap pendefinisian (define)

Tahap pendefinisian bertujuan untuk menetapkan dan mendefinisikan syarat-syarat pembelajaran melalui analisis tujuan dan materi pembelajaran. Pada tahap ini terdapat 5 langkah pokok yaitu: analisis awal untuk menganalisis permasalahan yang muncul pada saat proses pembelajaran fisika, analisis peserta didik untuk mengetahui karakteristik peserta didik, analisis tugas untuk menentukan KI, KD yang akan digunakan dalam penelitian, analisis konsep untuk menentukan konsep-konsep utama yang akan dibahas dalam pembelajaran dan terakhir menentukan tujuan pembelajaran yang disesuaikan dengan $\mathrm{KI}, \mathrm{KD}$ yang terlah ditentukan. 
2. Tahap perancangan (design)

Tujuan dari tahap ini adalah merancang perangkat pembelajaran. Tahap ini terdiri dari 41 angkah yaitu: membuat lembar validasi dengan mencantumkan kriteria tertentu untuk mengukur kelayakan perangkat pembelajaran yang dikembangkan, kemudian memilih media pembelajaran yang akan digunakan dalam perangkat pembelajaran, dan memilih format pembelajaran dan terakhir menyusun draf perangkat pembelajaran berupa silabus, RPP, dan LKPD yang disesuaikan dengan format pembelajaran yang telah ditentukan.

\section{Tahap pengembangan (develop)}

Tahap pengembangan merupakan tahap anrealisasi rancangan produk perangkat pembelajaran yang akan digunakan. Tahap pengembangan ini bertujuan menghasilkan dan memvalidasi perangkat pembelajaran berupa silabus, RPP dan LKPD. Validasi produk merupakan kegiatan menilai rancangan produk yang bertujuan untuk memperkecil tingkat kesalahan dalam tahap pengembangan. Kegiatan pengembangan dilakukan dengan memvalidasi perangkat pembelajaran oleh validator yakni 3 dosen fisika FKIP, Universitas Mataram dan selanjutnya melakukan revisi sesuai dengan masukan yang direkomendasikan oleh validator.

Data yang diperoleh dari hasil validasi berupa data kualitatif dan data kuantitatif. Data kualitatif berupa saran dan komentar dari validator, dan data kuntitatif berupa penilaian validator terhadap perangkat pembelajaran yang telah dikembangkan dengan mengisi lembar validasi berdasarkan kriteria penilaian sebagai berikut.

Tabel 1. AturanPemberian Skor

\begin{tabular}{lll}
\hline No & Kategori & Skor \\
\hline 1 & Sangat Baik & 4 \\
2 & Baik & 3 \\
3 & Cukup Baik & 2 \\
4 & Tidak Baik & 1 \\
\hline
\end{tabular}

(Sugiyono: 2017)

Data yang telah diperoleh dari hasil validasi selanjutnya dianalisis untuk memperoleh nilai validitasi dan reliabilitas dari perangkat pembelajaran yang telah dikembangkan dengan penjabaran sebagai berikut.

a. Validitas

Analisis validasi ahli dilakukan dengan cara:

$$
\text { Validitas }(V)=\frac{\text { Total skor validasi }}{\text { Total skor maksimal }} \times 100 \%
$$

Keterangan:

$\mathrm{V}=$ validitaspembelajaran

Dengan kriteria validitas:
Tabel 2. Kriteria Validitas Perangkat Pembelajaran

\begin{tabular}{lll}
\hline No & Skor & Kriteria \\
\hline 1 & $85,01-100,00 \%$ & Sangat valid \\
2 & $70,01-85,00 \%$ & Cukup valid \\
3 & $50,01-70,00 \%$ & Kurang valid \\
4 & $01,01-50,00 \%$ & Tidak valid \\
\hline
\end{tabular}

b. Reliabilitas

Tingkat reliabilitas suatu instrument menunjukkan berapa kali pun data tersebut diambil hasilnya akan tetap sama (Setyosari: 2012). Reliabilitas dalam penelitian ini menggunakan metode Borich yang dikenal dengan Percentage Agreement (PA) yaitu persentase kesepakatan antar penilai yang merupakan suatu persentase kesesuaian nilai antara penilai pertama dengan penilai kedua. Instrumen dikatakan reliabel jika nilai persentasi kesepakatannya lebih atau sama dengan 75\% (Borich: 1994). Percentage Agreement (PA) dirumuskan sebagai berikut:

$$
\text { Percentage Agreement }(\mathrm{PA})=\left(1-\frac{\mathrm{A}-\mathrm{B}}{\mathrm{A}+\mathrm{B}}\right) 100 \%
$$

Keterangan:

PA= Reliabilitas Instrumen Percentage Agreement

$\mathrm{A}=$ Skor penilaian yang lebih besar

$\mathrm{B}=$ Skor penilaian yang lebih kecil

\section{Hasil Dan Pembahasan}

\section{a. Pengembangan Perangkat Pembelajaran}

Tahap pendefinisian bertujuan untuk mendapatkan informasi tentang permasalahan yang muncul dalam pembelajaran fisika. Berdasarkan hasil observasi yang telah dilakukan di MAN 2 Mataram, pandemi covid-19 membuat peserta didik harus belajar dari rumah melalui internet yang dikenal denagn istilah daring (dalam jaringan). Guru menyampaikan materi pembelajaran dengan metode pembelajaran langsung melalui Whatsup dan Zoom, pada materi yang membutuhkan praktikum/demonstrasi guru memberikan video pembelajaran yang diambil dari internet hal ini membuat peserta didik seringkali kesulitan dalam memahami materi pembelajaran karena menurut peserta didik cara penjelasan guru kelas berbeda dengan cara penjelasan narasumber dari video pembelajaran tersebut sehingga penguasaan konsep fisika peserta didik masih kurang. Beberapa peserta didik sering tidak mengumpulkan tugas dan kurangnya keaktifan peserta didik dalam pembelajaran daring membuat guru tidak bisa menerapkan variasi metode pembelajaran lainnya.

Setelah mengetahui permasalahan yang muncul dalam pembelajaran dan karakteristik peserta didik selanjutnya menentukan KI, KD, konsep-konsep utama yang akan dibelajari dan membuat tujuan pembelajaran dari materi yang telah ditentukan. Materi 
dalam pengembangan perangkat pembelajaran ini adalah suhu, kalor dan perpindahan kalor.

Tahap kedua dari penelitian pengembangan adalah tahap perancangan yang bertujuan untuk merancang perangkat pembelajaran dan instrumen penelitian. Produk pengembangan yang dihasilkan dalam penelitian ini berupa perangkat pembelajaran aktif dengan metode practice rehearsal pairs. Perangkat pembelajaran yang dikembangkan dalam penelitian ini adalah silabus, RPP dan LKPD. Instrumen penelitian yang disusun dalam penelitian ini berupa lembar validasi yang divalidasi oleh ahli.

\section{b. Kelayakan Perangkat Pembelajaran}

Perangkat pembelajaran yang telah disusun kemudian divalidasi untuk mengetahui kelayakan dari perangkat pembelajaran tersebut oleh 3 ahli ( 3 orang dosen fisika FKIP Universitas Mataram). Berdasarkan hasil validasi diperoleh nilai analisis validitas dan reliabilitas terhadap peragkat pembelajaran yang telah disusun.

1. Validitas

Berdasarkan hasil validasi oleh validator diperloeh hasisl analisis validitas sebagai berikut.

Tabel 3: Analisis Validitas Perangkat Pembelajaran

\begin{tabular}{lcccll}
\hline Produk & V1 & V2 & V3 & $\begin{array}{l}\text { Total rata-rata } \\
\text { validitas }\end{array}$ & Kriteria \\
\hline Silabus & 2,7 & 3,7 & 3,3 & $80,83 \%$ & Cukup Valid \\
RPP & 2,8 & 3,8 & 3,4 & $83,33 \%$ & Cukup Valid \\
LKPD & 2,8 & 3,3 & 3,4 & $79,17 \%$ & Cukup Valid \\
\hline
\end{tabular}

Hasil analisis validitas berdasarkan hasil validasi dari 3 orang validator menunjukkan bahwa perangkat pembelajaran yang dikembangkan masuk dalam kriteria cukup valid, baik silabus, RPP maupun LKPD.

\section{Reliabilitas}

Berdasarkan hasil validasi oleh validator diperloeh hasisl analisis reliabilitas sebagai berikut.

Tabel 4: Analisis Reliabilitas Perangkat Pembelajaran

\begin{tabular}{llllll}
\hline Produk & $\begin{array}{l}\text { V12 } \\
(\%)\end{array}$ & $\begin{array}{l}\text { V23 } \\
(\%)\end{array}$ & $\begin{array}{l}\text { V13 } \\
(\%)\end{array}$ & $\begin{array}{l}\text { Rata-rata } \\
\text { Reliabilitas }\end{array}$ & Kriteria \\
\hline Silabus & 84,19 & 94,29 & 89,71 & $89,40 \%$ & Reliabel \\
RPP & 84,55 & 95,24 & 89,31 & $89,70 \%$ & Reliabel \\
LKPD & 89,35 & 93,07 & 91,17 & $91,20 \%$ & Reliabel \\
\hline
\end{tabular}

Hasil analisis reliabilitas menunjukkan bahwa perangkat pembelajaran yang dikembangkan masuk dalam kriteria reliabel karena memiliki nilai reliabilitas diatas $75 \%$.

\section{Kesimpulan}

Berdasarkan hasil penelitian dan pembahasan, maka diperoleh kesimpulan bahwa pengembangan perangkat pembelajaran aktif dengan metode practice rehearsal pairs layak digunakan dalam pembelajaran dengan revisi, karena hasil validitas produk penelitian memiliki kriteria cukup valid dan reliabel. Produk yang dikembangkan diharapkan dapat digunakan guna meningkatkan penguasaan konsep fisika.

\section{Daftar Pustaka}

Ardiansyah, B. (2013). Belajar dan Pembelajaran. Mataram: FKIP Press.

Borich, D. (2014). Observation Skills for Effective Teaching. Englewood Cliffs: Macmilan Publishing company.

Hikmawati. (2014). Strategi Pembelajaran Fisika. Mataram: FKIP Press.

Munfaridatus, A. (2018). Implementasi Strategi Practice Rehearsal Pairs Linghtening the Learning Climate dan Simulasi dalam Pembelajaran di Sekolah. Jurnal Pendidikan Sosialdan Agama Insuri Ponorogo. 1(1)

Rochmad. (2012). Desain Model Pengembangan Perangkat Pembelajaran Matematika. Jurnal Matematika FMIPA UNNES. 3(1). 2086-2334.

Setyosari, P. (2012). Metode Penelitian Pendidikan Dan Penembangan. Jakarta: Kencana.

Silberman, M. (2009). Active Learning (101 Strategi Pembelajaran Aktif). Yogyakarta: Pustaka Insan Madani.

Sugiyono. (2017). Statistika Untuk Penelitian. Bandung: Alfabeta.

Suprijono, A. (2014). Cooperatif Learning Teori \& Aplikasi PAIKEM. Yogyakarta: PustakaBelajar.

Suriani, T. \& Utami, K.B. (2019). Penerapan Strategi Pembelajaran Aktif Tipe Practice Rehearsal Pairs Dalam Pembelajaran Matematika Siswa Kelas VII SMPN 1 Ranah Pesisir. Jurnal Ilmiah Pendidikan Scholastic. 3(2).

Warsono, H. (2012). Pembelajaran Aktif: Teori Dan Asesmen. Bandung: Remaja Rosdakarya 